\title{
Evaluation of the properties and structure of nanocrystalline surface layers in relation to selected constructional materials resistant to abrasive wear
}

\section{Keywords:}

abrasive wear; nanocrystalline layers; abrasion plates; deposit weld

\begin{abstract}
The present paper is the result of the investigations of the properties and structure of nanocrystalline layers deposited from iron-based nanoalloy on steel S355N substrate by manual metal arc welding method (MMA) compared to selected abrasion-resistant construction materials currently used in industry. The resultant deposit welds were subjected to macro and microscopic metallographic examination. Working properties of obtained nanocrystalline deposits weld compared to currently used materials were evaluated based on the hardness, abrasive wear of metal-to-mineral. The results of deposits weld working properties measurements were compared with property of wear resistant steel HARDOX 400 type used as reference material.
\end{abstract}

\section{Introduction}

The current scientific, technical and economic issue is the problem of wear of machine parts caused by a decrease in working properties of the working surface. In most cases, wear mechanisms are very complex, they include many interrelated factors whose intensity of impact depends on the environment and working conditions. The variety of wear types leads to the specialization of construction materials in order to ensure the highest wear resistance of surface layers under specific operating conditions. One of the types of such materials are wear-resistant plates. The structure of the surface layer and its properties are the decisive elements on the durability of individual machine parts $[1 \div 5]$. For several years, there has been a dynamic progress of research on the development of new additional materials enabling the creation of layers characterized by unique properties and structure, different from the properties of the layers previously made. In particular, this applies to such material features as: hardness, resist-

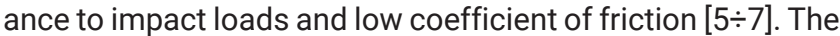
dynamic development of nanostructured materials predicts the increase in their application in welding technologies in the future. The different properties of materials with a nanostructured structure compared to steel mean that the use of nanomaterials in surfacing technologies brings new possibilities. These nanomaterials are single or multi-phase polycrystals characterized by a microstructural grain size of $1 \times 10^{-9}$ to $250 \times 10^{-9} \mathrm{~m}$. At the upper limit of this range, the term „very fine grain size" is used more often (grain size $250 \div 1000 \mathrm{~nm}$ ). Nano-crystalline materials are structurally characterized by a high volume share at the grain boundaries, which significantly changes their physical, chemical and mechanical properties in comparison to conventional coarse-grained materials, whose grain size is usually in the range of $10 \div 300 \mu \mathrm{m}$

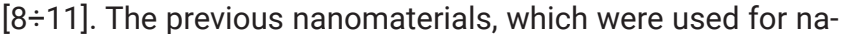
nostructured layers and coatings, showed many times higher resistance to wear compared to traditional steel materials. However, nanostructured materials do not have wide application in surfacing technologies due to high costs and continuous development of their production technology [12 $\div 14]$.

\section{Own research}

The research was aimed at comparing the properties and structure of the Fe-Cr-Nb-B nanocrystalline surface layers,

dr hab. inż. Jacek Górka, prof. PŚl; dr inż. Artur Czupryński; dr hab. inż. Marcin Adamiak, prof. PŚl; mgr inż. Adam Kopyść

- Silesian University of Technology, Poland;

Corresponding author: jacek.gorka@polsl.pl 
made by manual arc welding with a coated electrode with a diameter of $3.2 \mathrm{~mm}$, compared to the previously used construction materials resistant to abrasive wear. The reference material in the assessment of resistance to abrasive wear of metal-mineral type was the HARDOX 400 steel. The following materials were tested:

- a nanocrystalline layer made with a coated electrode - NANO (Fe-Cr-Nb-B),

- abrasion resistant plate - ABRECOPLATE,

- abrasion resistant plate - CDP,

- abrasion resistant layer made with coated electrode - ABRADUR 64,

- abrasion resistant layer made with GMA method using cermet wire with $50 \%$ share of WC,

- abrasion resistant HARDOX 400 sheet.

\section{The nanocrystalline layer made with $\mathrm{Fe}-\mathrm{Cr}-\mathrm{Nb}-\mathrm{B}$ coated} electrode

The Fe-Cr-Nb-B nanocrystalline layer (Tab. I) was made by manual arc welding with a $3.2 \mathrm{~mm}$ diameter coated electrode on a S355N steel substrate. MMA arc surfacing was carried out with constant current of positive polarity and current intensity of $100 \mathrm{~A}$ in the flat position (PA). During surfacing, the electrode was positioned at an angle of $90^{\circ}$ to the surface of the surfaced substrate. The surface of the sheet before the surfacing process was ground and pre-heated with a gas burner to a temperature of approx. $80^{\circ} \mathrm{C}$.

According to the manufacturer's data, the deposit weld of Fe-Cr-Nb-B nanocrystalline electrodes in a large volume consists of very hard boron carbide fractions evenly distributed in a half-amorphous iron alloy [15]. The padding weld should have high abrasion resistance and increased resistance to dynamic loads. The electrodes can be used for both constant current and alternating current surfacing. They ensure hardness of $67 \div 70 \mathrm{HRC}$.

\section{Abrasion resistant plate - ABRECOPLATE}

ABRECOPLATE abrasion resistant materials are produced in the form of: plates (straight, truncated, on special order), bars, buttons (in the shape of a dome, octagonal, protecting screws) [16]. ABRECOPLATE is a layered material composed of chromium-molybdenum white cast iron, metallurgically connected with a underlay plate made of a soft structural steel (Tab. II)

ABRECOPLATE's high abrasion resistance properties are due to the structure of the surface layer. The special heat treatment of cast iron allows to obtain a microstructure consisting of chromium-molybdenum carbides in an almost completely martensitic matrix. The base of these abrasive plates is soft structural steel. The cast iron is connected with

Table I. Chemical composition and hardness of tested deposit weld

\begin{tabular}{|c|c|c|c|c|c|c|c|}
\hline \multicolumn{7}{|c|}{ Chemical composition, \% } & \multirow{2}{*}{$\begin{array}{c}\text { Hardness } \\
\text { of deposit } \\
\text { weld }\end{array}$} \\
\hline $\mathrm{C}$ & $\mathrm{Cr}$ & $\mathrm{B}$ & $\mathrm{Nb}$ & $\mathrm{Mn}$ & $\mathrm{Si}$ & $\mathrm{Fe}$ & \\
\hline 1.4 & 15.2 & 4.0 & 3.4 & 0.4 & 0.4 & rest & $68 \div 70 \mathrm{HRC}$ \\
\hline
\end{tabular}

Table II. Chemical composition and physical characteristics of ABRECOPLATE

\begin{tabular}{|c|c|c|c|c|c|}
\hline \multicolumn{6}{|c|}{ Mass concentration of elements, \% } \\
\hline $\mathrm{C}$ & $\mathrm{Cr}$ & $\mathrm{Mo}$ & $\mathrm{Mn}$ & $\mathrm{Si}$ & $\mathrm{Ni}$ \\
\hline $2.8 \div 3.6$ & $14.0 \div 18.0$ & $2.3 \div 3.5$ & $0.5 \div 1.5$ & $1.0 \mathrm{max}$. & $5.0 \mathrm{max}$. \\
\hline \multicolumn{5}{|c|}{ Mechanical properties } \\
\hline Hardness, HB/HRC & Geat resistance, ${ }^{\circ} \mathrm{C}$ & Creep resistance, ${ }^{\circ} \mathrm{C}$ \\
\hline $700 / 64$ & \multicolumn{2}{|c|}{540} & \multicolumn{2}{|c|}{595} \\
\hline
\end{tabular}

the base by soldering with the use of a soft copper-based binder, which ensures a good transfer of stresses. An important advantage of ABRECOPLATE abrasive plates is also the content of abrasive material in relation to the base, which is $3: 1$.

\section{CDP plate}

Abrasion resistant plates are manufactured by hardfacing a metal sheet of non-alloy steel, low-alloy or high-alloy steel with gas shielded flux-cored wires or self-shielded flux-cored wires (Tab. III) [15].

The padded layer has a very high abrasion resistance and its standard thickness is $3 \div 18 \mathrm{~mm}$. Typical dimensions of abrasion resistant plates are: $1000 \times 2000 \mathrm{~mm}, 1500 \times 3000 \mathrm{~mm}$ and $2000 \times 3000 \mathrm{~mm}$. It is possible to cut flat elements of any shape from abrasion resistant plates and shape them by bending and rolling. They are attached to the regenerated substrate with fillet welds, continuous or intermittent, depending on the type of abrasive plate load. The high content of carbon, chromium and niobium allows obtaining a structure similar to that of cast iron with very hard chromium borides, niobium carbides and iron carbides.

Table III. Chemical composition of surface deposit weld

\begin{tabular}{|c|c|c|c|c|c|c|c|}
\hline \multicolumn{7}{|c|}{ Mass concentration of elements, $\%$} & \multirow{2}{*}{$\begin{array}{l}\text { Hardness } \\
\text { of deposit } \\
\text { weld }\end{array}$} \\
\hline C & $\mathrm{Cr}$ & B & $\mathrm{Nb}$ & $\mathrm{Mn}$ & $\mathrm{Si}$ & $\mathrm{Fe}$ & \\
\hline 5.2 & 22.0 & 1.8 & 7.0 & 0.4 & 0.4 & rest & $57 \div 62 \mathrm{HRC}$ \\
\hline
\end{tabular}

\section{Abrasion resistant layer made with ABRADUR 64 coated electrode}

The abrasion resistant layer was made by manual surfacing of S335JR steel with a coated electrode DIN 8555:E 10-UM-65-GR with a diameter of $5.0 \mathrm{~mm}$, and current intensity of $270 \mathrm{~A}$. The surfacing process was carried out using a buffer layer made with an ERWS 19-12-3 L coated electrode with a diameter of $3.25 \mathrm{~mm}$, and current intensity of $110 \mathrm{~A}$. The task of the buffer layer was to transfer the stresses between the base material and a hard padding weld. Chemical composition and properties of ABRADUR 64 coated electrode are given in Table IV.

Table IV. Chemical composition and properties of ABRADUR 64 covered electrodes [17]

\begin{tabular}{|c|c|c|c|}
\hline \multicolumn{3}{|c|}{ Mass concentration of elements, \% } & \multirow{2}{*}{$\begin{array}{c}\text { Hardness, } \\
\text { HRC }\end{array}$} \\
\cline { 1 - 2 } $\mathrm{C}$ & $\mathrm{Cr}$ & $\mathrm{Nb}$ & \\
\hline 7.0 & 24.0 & 7.0 & 64 \\
\hline
\end{tabular}

\section{Abrasion resistant layer made with GMA method using cermet wire}

The abrasion-resistant layer was made by single-layer GMA surfacing of $15 \mathrm{HM}$ steel with cermet wire on a nickel matrix with $50 \%$ share of tungsten carbide WC [15]. The chemical composition of the surfaced layer after chemical composition analysis is shown in Table V.

Table V. Chemical composition of layer formed by GMA with ceramo-metallic wire layer

\begin{tabular}{|c|c|c|c|c|c|}
\hline \multicolumn{7}{|c|}{$\begin{array}{c}\text { The mass concentration of the elements } \\
\text { of abrasion resistant layer, \% }\end{array}$} \\
\hline $\mathrm{Ni}$ & $\mathrm{C}$ & $\mathrm{Si}$ & $\mathrm{Cr}$ & $\mathrm{B}$ & WC \\
\hline Rest & 0.4 & 2.5 & 3.0 & 1.5 & 50 \\
\hline
\end{tabular}




\section{HARDOX 400 steel sheet}

Hardox steels are defined as „high-quality abrasion resistant steels". The group of these materials is derived from low-alloy steel for thermal improvement and belongs to a new generation of machinable and weldable structural steels. Materials made of Hardox steel are used where resistance to abrasion is required in the presence of variable loads, e.g. feeders, crushers, sieves, shaft necks, elements of incline haulage, conveyors, blades, gear and chain wheels, dumpers, loaders, trucks, dozers, buckets and screw conveyors. All types of HARDOX steel are delivered in hardened condition (in water), and in the case of relevant required hardness, tempering is also carried out. These steels can be bent, cut, and machined by drilling, milling and turning under strictly defined conditions. HARDOX sheets can be machined using high speed steel (HSS) or tools made of sintered carbides [18]. The chemical composition and properties of HARDOX 400 steel are given in Table VI.

\section{Testing of abrasion resistance of the metal-mineral type according to ASTM G65-00}

The tests of resistance to abrasive wear of selected materials were carried out on a test bench, made in accordance with ASTM G65-00. The procedure A was used for the tests, which is the most demanding examination of abrasion resistance. During the test, the sample was mounted in a special holder pressing it to a rubber wheel with a diameter of $228.6 \mathrm{~mm}$. The test sample was pressed against the rubber wheel with a force of $130 \mathrm{~N}$. Abradant, in the form of granular sand, was delivered through the nozzle in place of the sample

Table VI. Chemical composition and mechanical properties of HARDOX 400

\begin{tabular}{|c|c|c|c|c|c|}
\hline \multicolumn{5}{|c|}{ Mass concentration of elements, \% } \\
\hline $\mathrm{C}$ & $\mathrm{Mn}$ & $\mathrm{Mo}$ & $\mathrm{Cr}$ & $\mathrm{Si}$ & $\mathrm{Ni}$ \\
\hline $0.14 \div 0.32$ & 1.60 & $0.25 \div 0.60$ & $0.30 \div 1.40$ & 0.70 & $0.25 \div 1.50$ \\
\hline \multicolumn{5}{|c|}{ Mechanical properties } \\
\hline Hardness, HB & $\begin{array}{c}\text { Ultimate tensile } \\
\text { strength, MPa }\end{array}$ & Yield strength, MPa \\
\hline $370 \div 430$ & \multicolumn{2}{|c|}{1250} & 1000 \\
\hline
\end{tabular}

contact with the rubber wheel. The abradant flow rate was $300 \div 400 \mathrm{~g} / \mathrm{min}$. The wheel rotated in the direction corresponding to the abradant flow, at a speed of $200 \mathrm{rpm}$ and made 6000 revolutions. The samples tested had a dimension of $25 \times 75 \times \mathrm{mm}$. The mass loss was determined using a laboratory scale with a measurement accuracy of $0.0001 \mathrm{~g}$. In order to compare the results of resistance to abrasive wear, a measurement of the density of plates and abrasive layers was carried out. The volume loss of the sample $\left[\mathrm{mm}^{3}\right]$, formula (1), table VII, figure 1 were taken as a measure of abrasibility.

Volume loss $\left[\mathrm{mm}^{3}\right]=\frac{\text { loss of weight }[\mathrm{g}]}{\text { density }\left[\mathrm{g} / \mathrm{cm}^{3}\right]} \times 1000$

\section{Metallographic examinations}

The metallographic microscopic examinations allowed to determine the microscopic structure of the examined materials. The observations which were carried out did not show any internal defects in the layers made by welding methods and material defects in the case of HARDOX 400 sheets as well as ABRECOPLATE and CDP plates (Fig. 2).

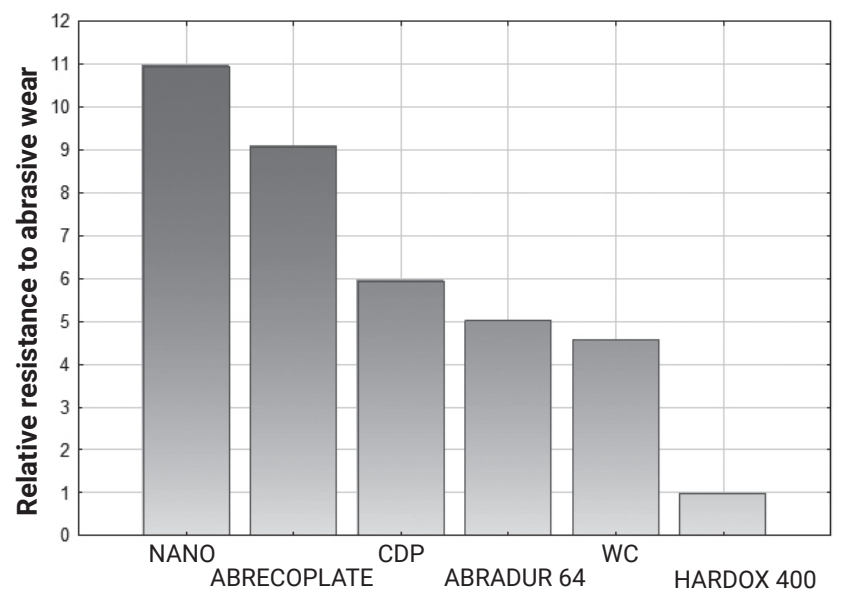

Type of material

Fig. 1. Comparison of the results of relative abrasive wear resistance of selected construction materials

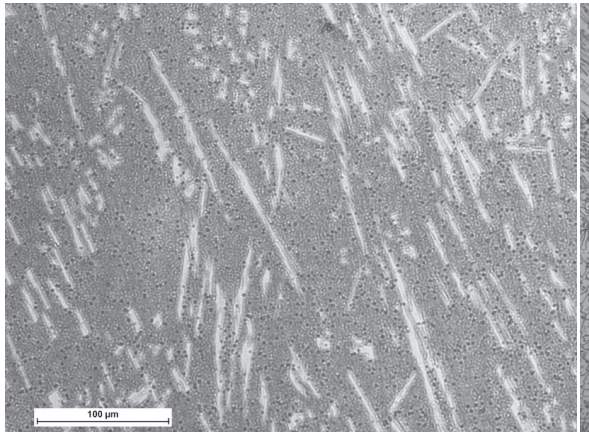

NANO

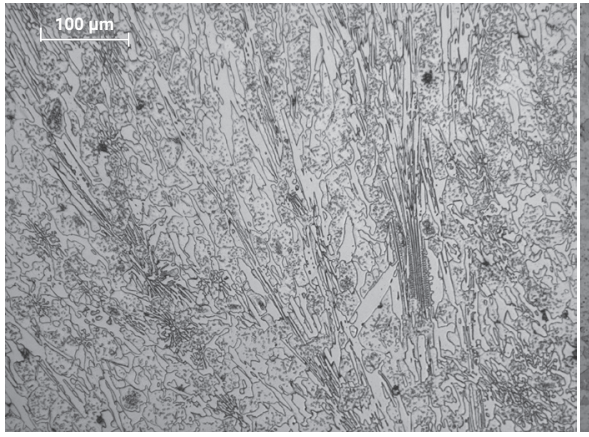

ABRADUR 64

Fig. 2. Microstructure of construction materials

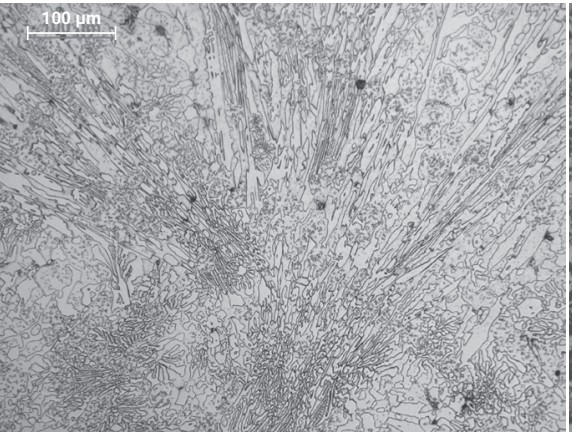

ABRECOPLATE

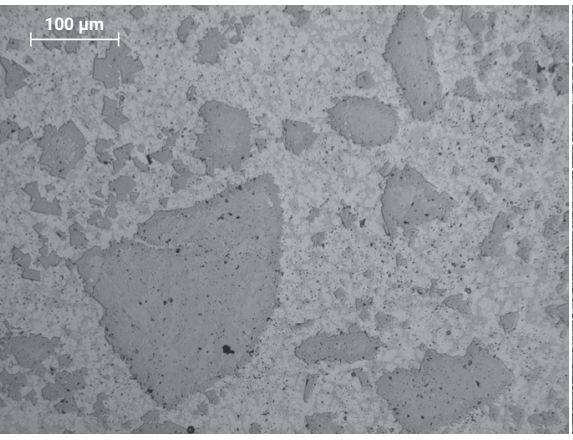

WC

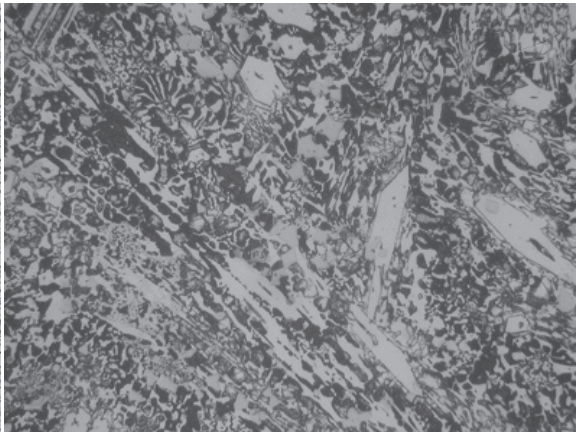

CDP

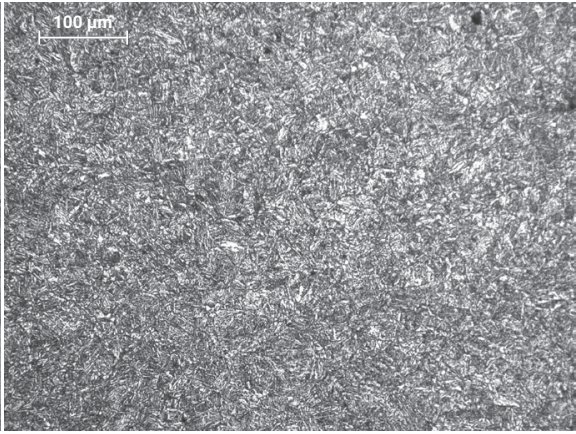

HARDOX 400 
Table VII. ASTM G65-00 abrasion resistance test results

\begin{tabular}{|c|c|c|c|c|c|c|c|}
\hline $\begin{array}{c}\text { Symbol/density } \\
{\left[\mathrm{g} / \mathrm{cm}^{3}\right]}\end{array}$ & $\begin{array}{l}\text { Sample } \\
\text { number }\end{array}$ & $\begin{array}{c}\text { Weight } \\
\text { of the sample } \\
\text { before testing } \\
\text { [g] }\end{array}$ & $\begin{array}{c}\text { Weight } \\
\text { of the sample } \\
\text { after testing } \\
\text { [g] }\end{array}$ & $\begin{array}{c}\text { Loss of weight } \\
{[\mathrm{g}]}\end{array}$ & $\begin{array}{c}\text { Average } \\
\text { weight loss } \\
\text { [g] }\end{array}$ & $\begin{array}{c}\text { Average } \\
\text { volume loss } \\
{\left[\mathrm{mm}^{3}\right]}\end{array}$ & $\begin{array}{c}\text { Relative } \\
\text { resistance } \\
\text { to abrasive } \\
\text { wear* }\end{array}$ \\
\hline \multirow{2}{*}{ NANO/8.78 } & 1 & 102.9477 & 102.8393 & 0.1084 & \multirow{2}{*}{0.1113} & \multirow{2}{*}{12.6765} & \multirow{2}{*}{10.95} \\
\hline & 2 & 101.7964 & 101.6821 & 0.1143 & & & \\
\hline \multirow{2}{*}{ ABRECOPLATE/7.5961 } & 1 & 173.7335 & 173.6133 & 0.1202 & \multirow{2}{*}{0.11635} & \multirow{2}{*}{15.3170} & \multirow{2}{*}{9.07} \\
\hline & 2 & 173.6714 & 173.5589 & 0.1125 & & & \\
\hline \multirow{2}{*}{$\mathrm{CDP} / 7.1724$} & 1 & 128.6154 & 128.4378 & 0.1776 & \multirow{2}{*}{0.1697} & \multirow{2}{*}{23.3881} & \multirow{2}{*}{5.94} \\
\hline & 2 & 128.9438 & 128.7821 & 0.1617 & & & \\
\hline \multirow{2}{*}{ ABRADUR 64/7.1544 } & 1 & 136.2893 & 136.0933 & 0.1960 & \multirow{2}{*}{0.19825} & \multirow{2}{*}{27.7102} & \multirow{2}{*}{5.01} \\
\hline & 2 & 139.6675 & 139.4670 & 0.2005 & & & \\
\hline \multirow{2}{*}{ WC/10.6808 } & 1 & 179.6026 & 179.3009 & 0.3017 & \multirow{2}{*}{0.32360} & \multirow{2}{*}{30.2974} & \multirow{2}{*}{4.58} \\
\hline & 2 & 181.8750 & 181.5295 & 0.3455 & & & \\
\hline \multirow{2}{*}{ HARDOX 400/7.7115 } & 1 & 62.1029 & 61.0320 & 1.0709 & \multirow{2}{*}{1.0691} & \multirow{2}{*}{138.8705} & \multirow{2}{*}{1.00} \\
\hline & 2 & 62.5591 & 61.4918 & 1.0673 & & & \\
\hline
\end{tabular}

\section{Hardness measurement}

In order to determine the hardness of the tested materials, hardness measurement was carried out in 5 places on the weld face / sheet surface using Rockwell HRC method, and in 4 places on the padding weld / sheet cross-section using the Vickers method at a load of $1000 \mathrm{~g}$ (Fig. 3 and 4). The results of hardness measurements are presented in Table VIII and Figure 5.

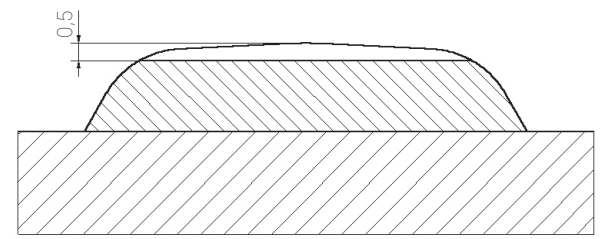

Fig. 3. Preparation for hardness testing
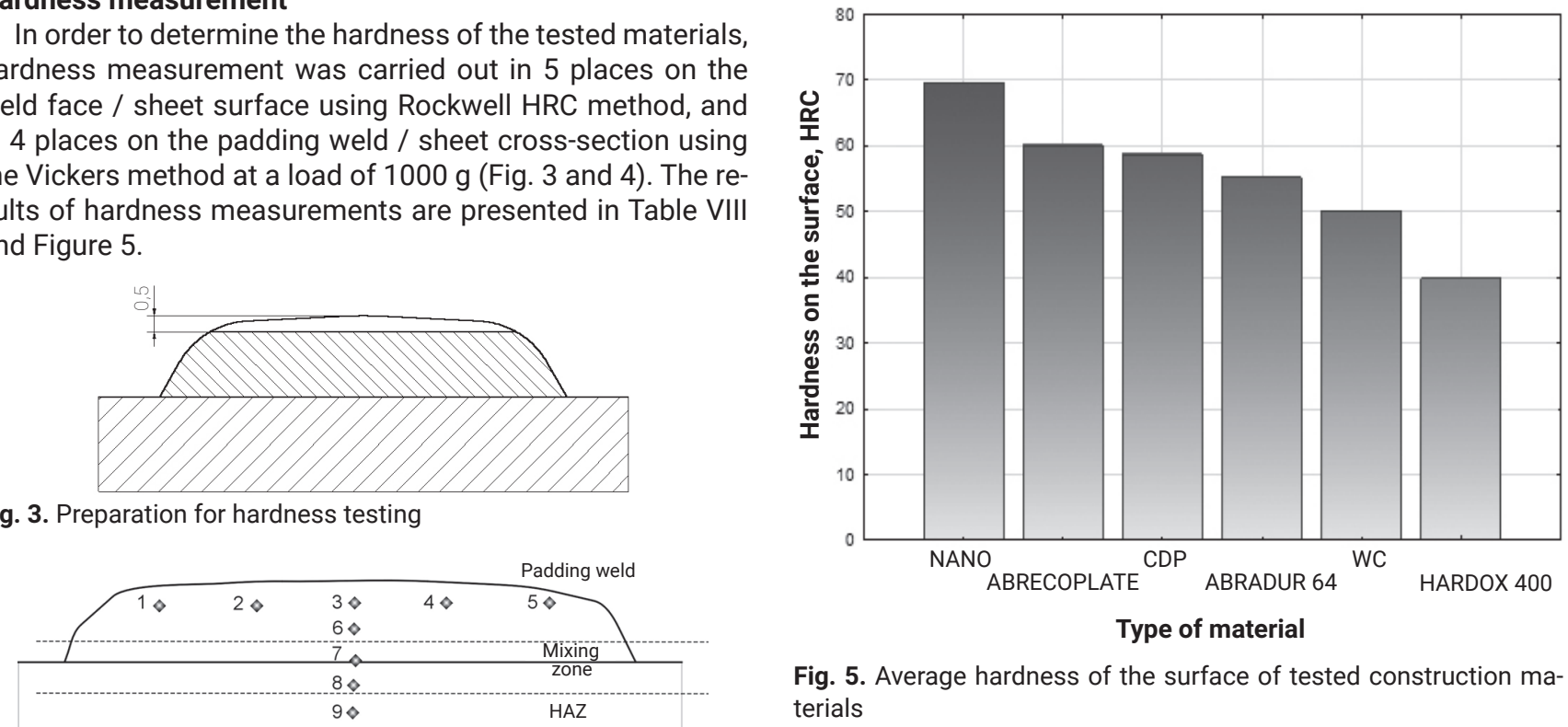

Type of material

Fig. 5. Average hardness of the surface of tested construction materials

Fig. 4. Hardness test area

Table VIII. Hardness testing results on the face and cross section of deposit welds and sheets

\begin{tabular}{|c|c|c|c|c|c|c|c|c|c|c|}
\hline \multirow{2}{*}{ Material } & \multicolumn{4}{|c|}{ Hardness HRC } & \multicolumn{5}{c|}{ Hardness HV1 } \\
\cline { 2 - 12 } & 1 & 2 & 3 & 4 & 5 & Average & 6 & 7 & 8 & 9 \\
\hline NANO & 69 & 70 & 69 & 71 & 69 & 69.60 & 679 & 289 & 179 & 188 \\
\hline ABRECOPLATE & 60 & 58 & 61 & 61 & 62 & 60.04 & 663 & 154 & 148 & 106 \\
\hline CDP & 62 & 59 & 58 & 61 & 58 & 58.70 & 643 & 299 & 179 & 182 \\
\hline ABRADUR 64 & 57 & 56 & 57 & 54 & 52 & 55.20 & 556 & 174 & 304 & 290 \\
\hline WC & 54 & 50 & 48 & 51 & 49 & 50.04 & 563 & 486 & 180 & 167 \\
\hline HARDOX 400 & 41 & 40 & 39 & 40 & 39 & 39.80 & 380 & 378 & 377 & 378 \\
\hline
\end{tabular}




\section{Conclusions}

The metallographic examinations of the materials selected for the tests did not show any internal and external defects of the layers made by manual surfacing with coated electrodes and surfacing using GMA method. Measurement of the grain size of the crystallographic nanocrystalline microstructure of Fe-Cr-Nb-B type made using the Xpert PRO X-ray diffractometer from PANalytical showed that the layers were made of crystallites at $20 \mathrm{~nm}$, which classifies these layers as nanocrystalline. The ABRECOPLATE board has a structure of white cast iron with the precipitation of chromium-molybdenum carbides. To connect this plate with a low carbon steel support plate, a soft binder was used on the copper matrix, which perfectly transfers the stresses occurring between the layers. In the case of a CDP, the surface layer structure is a chromium cast iron with a lot of primary carbides. The layer made with coated electrodes ABDADUR 64 has a structure of the eutectic iron with numerous precipitates of niobium and chromium carbides. The use of austenitic steel buffer layer in this case allowed to avoid cracks that could propagate to the substrate material. The layer made by GMA surfacing with a cermet wire is characterized by a nickel matrix with numerous WC carbides. It can be observed that as a result of the thermal cycle, the WC carbides are partially dissolved, which may reduce the abrasion resistance of such layers. HARDOX 400 is characterized by the structure of tempered martenzite. The hardness measurements carried out on the ground face of abrasion resistant layers showed that all materials have a hardness similar to the hardness given by the manufacturers. The highest hardness on the surface is characterized by a nanocrystalline layer, hardness of $70 \mathrm{HRC}$. The tests of resistance to abrasive wear of the metal-mineral type, according to ASTM G65-00, have shown that the best usable properties are characterized by a layer made of Fe-Cr$\mathrm{Nb}-\mathrm{B}$ alloy. The abrasion resistance of the metal-mineral type of this material is 11 times higher than in the case of a typical HARDOX 400 abrasion resistant sheet.

\section{References}

[1] A. Lisiecki, Titanium Matrix Composite Ti/TiN Produced by Diode Laser Gas Nitriding, Metals 5/1 (2015), 54-69.

[2] D. Janicki, Disk laser welding of armor steel, Archives of Metallurgy and Materials (2014) vol. 59(4), 1641-1646.

[3] R. Burdzik, Ł. Konieczny, Z. Stanik, P. Folęga, A. Smalcerz, A. Lisiecki, Analysis of impact of chosen parameters on the wear of camshaft, Archives of Metallurgy and Materials (2014), vol. 59(3), 957-963.

[4] D. Janicki, Power Diode Laser Cladding of Wear Resistant Metal Matrix Composite Coatings, Solid State Phenomena, Mechatronic Systems and Materials, (2013), vol. 199, 587-592.

[5] T. Chmielewski, A. Golanski, New method of in-situ fabrication of protective coatings based on Fe-Al intermetallic compounds, Proceedings of the institution of mechanical engineers part B-journal of engineering (2011), vol. 225, 611-616.

[6] D. Golański, G. Dymny, M. Kujawińska, T. Chmielewski: Experimental Investigation of Displacement/Strain Fields in Metal Coatings Deposited on Ceramic Substrates by Thermal Spraying, Solid State Phenomena (2015), vol. 240, 174-182.

[7] Ch. P. Jr Poole, F. J. Ownes, Introduction to Nanotechnology, Wiley (2003), 1-8.

[8] S. Boncel, J. Górka, S.P. Shaffer Milo, K. Koziol, Binary salt' of hexane-1,6-diaminium adipate and carbon nanotubate' as a synthetic precursor of carbon nanotube/Nylon-6,6 hybrid materials, Polymer Composites (2014), vol. 35(3), 523-529.
[9] G. Heath, Nanotechnology and welding - actual and possible future applications, CASTOLIN-EUTECTIC SEMINAR, Brussels, Belgium, 25-25.10.2006, 15-19.

[10] J. Górka, A. Czupryński, Testing of flame sprayed $\mathrm{ZrO}_{2}$ matrix coatings containing CaO, Applied Mechanics and Materials (2015), vols. 809-810, 501-506.

[11] W. Włosinski, T. Chmielewski, Plasma-hardfaced chromium protective coatings-effect of ceramic reinforcement on their wettability by glass, Contributions of Surface Engineering To Modern Manufacturing And Remanufacturing 3rd International Conference on Surface Engineering (2002), 48-53.

[12] S. Boncel, J. Górka, S. P. Shaffer Milo, K. Koziol, Shear-induced crystallisation of molten isotactic polypropylene within the intertube channels of aligned multi-wall carbon nanotube arrays towards structurally controlled composites, Materials Letters (2014), vol. 116, 53-56.

[13] U. Reisgen, L. Stein, B. Balashov, C. Geffers, Nanophase hardfaced coatings, Materialwissenschaft und Werkstofftechnik (2008), vol. 39(11), 791-794.

[14] A. Czupryński, J. Górka, M. Adamiak, Examining properties of arc sprayed nanostructured coatings, Metalurgija (2016), 55/2, 173-176.

[15] Materiały reklamowe: www.castolin.com

[16] Materiały reklamowe: www.canadianweartech.com

[17] Materiały reklamowe: www.hbt-weld.cz

[18] Materiały reklamowe: www.ssab.pl 